\title{
ПРОБЛЕМЫ ДИСТАНЦИОННОЙ ПРОФЕССИОНАЛЬНОЙ СЛУЖЕБНОЙ ДЕЯТЕЛЬНОСТИ ГОСУДАРСТВЕННЫХ ГРАЖДАНСКИХ СЛУЖАЩИХ РОССИЙСКОЙ ФЕДЕРАЦИИ В УСЛОВИЯХ РАСПРОСТРАНЕНИЯ НОВОЙ КОРОНАВИРУСНОЙ ИНФЕКЦИИ
}

\author{
(c) 2020 Дакашев Магомед-Эми Жабраилович \\ начальник отдела государственной службы и кадров \\ Администрация Главы и Правительства Чеченской Республики, Чеченская Респ., Грозный \\ E-mail magomed.dakashev@mail.ru \\ (c) 2020 Ибрагимов Юсуп Муслимович \\ ассистент кафедры теории и технологии социальной работы \\ Чеченский государственный университет, Чеченская Респ., Грозный \\ E-mail yusuf_ibr@mail.ru
}

В настоящем научном исследовании раскрывается тематика дистанционной профессиональной служебной деятельности государственных гражданских служащих, в условиях распространения новой коронавирусной инфекции (2019-nCoV).

B содержательной части научного исследования регламентируются основополагающие условия дистанционной профессиональной служебной деятельности, с раскрытием принципиальных свойств каждого условия.

В заключительной части научного исследования регламентируется вывод о необходимости изменений в федеральном законодательстве о государственной гражданской службе Российской Федерации, в части дополнения нормативной части институтом дистанционной профессиональной служебной деятельности, а также о необходимости дополнительных бюджетных ассигнований государственных органов, направленных на организационно-технические мероприятия по переводу сотрудников на дистанционную профессиональную служебную деятельность.

Ключевые слова: дистанционная профессиональная служебная деятельность, федеральное законодательство, институт, кадровые мероприятия, юридические мероприятия, организационнотехнические мероприятия.

В настоящий период регламентации институт дистанционной служебной деятельности в государственной гражданской службе Российской Федерации находится на стадии разработки и структуризации в системе государственной гражданской службы Российской Федерации.

Российская Федерация, применяя и внедряя конгломерат трудовых отношений, регулирующих дистанционную работу, не совсем корректно подходит к вопросу существования дистанционной служебной деятельности на государственной гражданской службе.

Это объясняется тем, что реализация дистанционной служебной деятельности государственных гражданских служащих Российской Федерации была вызвана новой коронавирусной инфекцией (2019-nCoV).

С учетом изложенного, актуальность темы настоящего научного исследования заключается в правильном толковании возможностей законодательного закрепления института дистанционной служебной деятельности в государственной гражданской службе Российской Федерации.

В этой связи, структурированное рассмотрение тематики дистанционной служебной деятельности, является фактическим обстоятельством к правильному пониманию предмета настоящего научного исследования.

Федеральное законодательство о государственной гражданской службе Российской Федерации не предусматривает института дистанционной профессиональной служебной деятельности [1].

Система государственной гражданской службы Российской Федерации, является самостоятельной институциональной системой государственной системы, применяющая нормы трудового права в той мере, к которой не пред- 
усмотрена законодательством о государственной гражданской службе.

Нормативное правовое пространство Российской Федерации под дистанционной профессиональной служебной деятельностью понимает осуществление государственными гражданскими служащими Российской Федерации должностных обязанностей без снижения производительности труда, являющегося основой функционирования государственного органа, вне места расположения государственного органа, по месту пребывания, при условии использования для выполнения должностных обязанностей и для осуществления взаимодействия между непосредственным руководителем и гражданскими служащими по вопросам, связанным с их выполнением, информационных, телекоммуникационных сетей, в том числе сети «Интернет».

В условиях распространения новой коронавирусной инфекции (2019-nCoV), государственные органы Российской Федерации, в соответствии с Указом Президента Российской Федерации от 25 марта 2020 года № 206 «Об объявлении в Российской Федерации нерабочих дней», единовременно в определенной процентной составляющей государственных гражданских служащих перешли на дистанционную профессиональную служебную деятельность [2].

Вместе с тем, представители нанимателя государственных гражданских служащих при переводе своих сотрудников на дистанционную профессиональную служебную деятельность столкнулись с юридическими, организационными и финансовыми затруднениями.

Юридические затруднения представителя нанимателя касались, прежде всего, в отсутствии институциональных норм, регулирующих перевод сотрудников на дистанционную служебную деятельность [3].

В этой связи, руководителям государственных органов приходилось утверждать локальные нормативные правовые акты о дистанционной профессиональной служебной деятельности, с закреплением основополагающих аспектов структуризации служебной деятельности.

Несмотря на то, что Российская Федерация движется по пути минимизации бюрократии в государственных органах, внедряя современные технологии информатизации документооборота, порядки государственных органов о дистанционной профессиональной служебной деятель- ности добавили огромное количество бумажной работы кадровым, юридическим и техническим службам государственных органов.

Кадровые службы государственных органов при переводе на дистанционную служебную деятельность должны были требовать от всех сотрудников, переходящих на удаленный доступ заявления о согласии на переход, сформировать приказы на каждого работника о переводе удаленный доступ, а также систематизировать табель учета рабочего времени под постоянным контролем за деятельностью сотрудников, переведенных на удаленный доступ работы [4].

Юридические службы государственных органов должны были сформировать обширный перечень локальных нормативных правовых актов, регулирующих переход на дистанционную профессиональную служебную деятельность.

С самыми большими проблемами столкнулись технические службы государственных органов при переводе сотрудников аппарата на дистанционную профессиональную служебную деятельность, так как технические службы должны были обеспечить рабочее место переведенного на удаленный доступ работы сотрудника.

Так, при переводе сотрудника на дистанционную профессиональную служебную деятельность, представитель нанимателя посредством технической службы государственного органа становился обязанным осуществить следующие мероприятия:

1. Установление доступа к информационнотелекоммуникационной сети «Интернет»;

2. Предоставление электронной цифровой подписи, для осуществления распорядительных функций;

3. Установления антивирусного средства;

4. Создания канала безопасной связи;

5. Обеспечение защиты персональных данных сотрудника;

6. Предоставления информационной техники, для осуществления функциональных обязанностей;

7. Предоставления доступа к открытым информационным системам государственного органа;

8. Техническая поддержка при технических неполадках;

9. Безусловная переадресация вызовов со стационарных рабочих телефонов на рабочие и личные мобильные телефоны;

10. Возможность проведения аудио- и виде- 
оконференций [5].

Кроме того, представитель нанимателя при переводе сотрудников государственного органа становился обязанным провести определенную просветительскую работу, в частности касающуюся, что при дистанционной профессиональной служебной деятельности гражданские служащие обязаны соблюдать установленные законодательством о государственной гражданской службе и о противодействии коррупции обязанности, ограничения и запреты, требования к служебному поведению и несут ответственность за их нарушение и несоблюдение служебной дисциплины.

Также предусматривается и обязанности сотрудников переведенных на дистанционную профессиональную служебную деятельность, по информированию представителя нанимателя об адресе места своего нахождения, номере мобильного телефона.

Сотрудники государственного органа должны знать и то, что на период дистанционной профессиональной служебной деятельности:

сохраняется режим служебного времени и времени отдыха;

гражданские служащие обязаны при необходимости по поручению непосредственного руководителя прибыть для исполнения служебных поручений по месту расположения государственного органа [6].

Однако, самой большой проблемой для представителя нанимателя, является отсутствие финансирования для перевода сотрудников на дистанционную профессиональную служебную деятельность.

Как было обозначено в предыдущих абзацах настоящей научной работы представитель нанимателя при переводе сотрудников на удаленный доступ, обязан произвести определенные технические мероприятия, вместе с тем, данные мероприятия влекут значительные финансо- вые вложения, которые в условиях незапланированности новой коронавирусной инфекции (2019-nCoV), в бюджете государственного органа предусмотрены не были.

С учетом изложенного отображается вопрос:

«Каким образом, и на какие финансовые ассигнования были переведены сотрудники государственных органов на дистанционную служебную деятельность?».

Ответ очень прост, дистанционная профессиональная служебная деятельность реализована была без соблюдения требований, в большинстве государственных органах работники просто ушли в «оплачиваемый отпуск».

В этой связи и с учетом того, что новая коронавирусная инфекция (2019-nCoV) не прекратила своего существования и все еще наносит колоссальный урон здоровью человека и экономике Российской Федерации, отображается, что органам государственной власти Российской Федерации необходимо:

1. Внести изменения в федеральное законодательство о государственной гражданской службе Российской Федерации, в части нормативного закрепления института дистанционной профессиональной служебной деятельности;

2. Представить дополнительные финансовые влияния в бюджеты государственных органов на организационно-техническое обеспечение перевода государственных гражданских служащих Российской Федерации на дистанционную профессиональную служебную деятельность.

В заключение хотелось бы отметить, что научная доктрина имеет большое значение в процессе становления всей государственной системы, и я надеюсь, что данная работа займет свое заслуженное место в построении нового института государственной гражданской службы Российской Федерации.

\section{Библиографический список}

1. Федеральный закон от 27 июля 2004 года № 79-Ф3 «О государственной гражданской службе Российской Федерации»;

2. Указ Президента Российской Федерации от 25 марта 2020 года № 206 «Об объявлении в Российской Федерации нерабочих дней»;

3. Информация Министерства труда и социальной защиты Российской Федерации от 23 марта 2020 года «Вопросы-ответы по организации удаленной работы и оформлению больничных в период компании по противодействию распространения коронавируса;

4. Письмо Министерства труда и социальной защиты Российской Федерации от 21 апреля 2020 года № 264/10/B-9451; 
5. Письмо Министерства труда и социальной защиты Российской Федерации от 2 апреля 2020 года № 264/10/B-9421;

6. Письмо Министерства труда и социальной защиты Российской Федерации от 19 августа 2020 года № 264/10/B-10348. 